\section{MAKING AND PRESENTATION OF SCIENTIFIC FILMS}

A JOINT meeting of the Association for Scientific Photography and the Scientific Film Association was held at the Ministry of Information on June 24, papers being given by the presidents of the two Associations and by Mr. Geoffrey Bell. Two films were projected, "Control Room" and "Nitrous 0xide-Oxygen-Ether Anæsthesia".

Mr. Arthur Elton, president of the Scientific Film Association, in opening the meeting, welcomed those present on behalf of the two Associations. He said that they could and should be complementary, and that the regions where they overlapped should constitute a strong bond rather than a weakness. He was glad that they were in fact working together and assisting each other materially. To achieve democratic self-government in any country, it is necessary for the citizens to have a knowledge of the scientific processes which govern their lives. The Association for Scientific Photography and the Scientific Film Association are ultimately engaged in public education; while it is not necessarily desirable for everyone to be able to solve a differential equation, the more informed the general public is, the less the danger of its being led away by filibusters such as those who had led away the countries of our enemies.

Mr. Elton then defined the fields covered by the two Associations. The Scientific Film Association, besides seeking to spread the general principles of scientific thought by means of the film, is engaged actively in the more practical problems of the production and distribution of scientific films for the public, and of specialized training films for engineers, chemists, physicists and so forth. The Association for Scientific Photography is concerned with the uses of still photography and cinematography as instruments of scientific research. While the two bodies may appear to be serving separate fields, their functions actually tend to overlap and support each other. For example, a scientific worker might use film in connexion with an investigation, say, for the analysis of high-velocity movements by means of the ultra-speed cine-camera. Sooner or later, he would want to tell people what he had done and therefore to show the film. Unless he was careful his record might well be incomprehensible to all except the specialist. With proper preparation, however, the film could be as useful a method of communication as a published paper. This is where the two Associations overlap most, for they can give advice both on the technique of preparing the film and on its method of presentation and distribution.

Mr. Geoffrey Bell, speaking on "Shooting a Scientific Film", illustrated his talk with "Control Room", a film which was made in Bristol. This show's how' the Civil Defence organization works in Great Britain. Though made primarily for American and for general home audiences, the film has also been used for showing to Civil Defence personnel, many of whom did not know how their huge and new organization worked as a whole. The film shows the nature of the technical problems of different branches of Civil Defence and the technique used to achieve co-ordination between these branches. For example, if the telephone engineers and the waterworks engineers want to repair their respective services in the same bomb crater, it is not enough that each should have pre- pared emergency measures for such a case; there obviously must be co-ordination between the two services. Mr. Bell dealt particularly with the problem of getting this kind of subject-matter converted into film terms. The whole technique of Civil Defence serves in the film as a means of studying the processes of community life, although they are seen in a special light, functioning under the stress of air-raids.

After the film had been screened Mr. Bell pointed out the value of the animated diagram for presenting an abstract process, in this case the procedure by which co-ordination between individual services was achieved through a series of different 'control centres'. He then selected from the film examples of various technical devices and methods of exposition.

One incident was used as typical of the problems of the public services and their relations to the com. munity. The film shows damage to a high-voltage main cable, leaving Avonmouth docks without their normal supplies of electric power. A method of temporary jointing of 33,000 -volt cable is shown which takes six hours, instead of the seventy-two hours needed for a permanent jointing. The skill and resource of the electrical engineers is shown to be related directly with the restarting of activity in the docks, and off-loading from ships of essential supplies. Films enable one to show, in a convincing fashion, that detailed aspects of one technical problem can be related with much wider issues affecting the community.

Prof. J. Yule Bogue, president of the Association for Scientific Photography, speaking on "The Production of Scientific Films for Biological and Medical Purposes", divided films into two main groupsthose making no new contribution to knowledge but presenting in a suitable form the knowledge at our disposal, and those making a new contribution to knowledge. $\mathrm{He}_{\theta}$ then dealt with the former group and followed the making of such a film, from the consideration of its subject-matter for suitability for film treatment, through possible methods of construction, the writing of the script, the photographic techniques involved and the actual shooting of the film, to the cutting, editing and final presentation*.

Prof. Bogue stressed that whether a professional film unit is employed or the film is made by those normally engaged in photography in the department, it was essential to decide all the preliminary work, and to write the complete script, before a foot of film is shot. Although anything scientific implies an orderly presentation of the facts in an objective manner, it is unfortunately true to say that many biological and medical films are neither orderly nor objective although labelled scientific. This is almost always caused by lack of planning and insufficient appreciation of the possibilities of the film.

Prof. Bogue also dealt with the choice of making a film in sound or silent. He believes that, if the worker's or teacher's opinion has to be considered, the film should be silent, but where the film is used to demonstrate a particular scientific discovery or an applied technique by an acknowledged expert in the field, then it should carry a recorded commentary. Having decided this, it is necessary to prepare a full shooting script based on a very clear, short, model lecture manuscript of the subject. Only shots essential to the film should be included, and all camera instructions

* A full report can be obtained from the Secretary, Association for Scientific Photography, Tavistock House North, Tavistock Square, London, W.C.1. 
should be clearly given; this requires a full visualization of the finished film while writing the seript. When the script is complete, it is highly desirable to send copies to colleagues in the same field for their comments. This usually improves a film very much; it should be noted, however, that two or three outside critics are sufficient and a committee should be avoided.

After a full discussion of the technical details of the filming and of the apparatus used, Prof. Bogue stressed the need for keeping the original film intact and employing a duplicate for cutting and editing, particularly when "Kodachrome" is used. The script should be broken down into shots, each on an index card with full technical information; the editing can then be carried out largely from this file. This is, of course, the stage at which the film is made or spoilt. The best films demand good presentation if they are to be used successfully. A good-quality projector and screen, suitable for the size of hall and audience, are essential.

After the screening of "Nitrous Oxide-OxygenEther Anæsthesia", there was a discussion which ranged over detailed problems of technique in film making, as well as wider issues regarding the production and use of scientific films. Among the matters discussed were the illumination most suitable for the photographing in colour of fatty tissues, and the desirability of making films on specialized subjects about which there might be controversy.

\section{TECHNICAL EDUCATION IN THE U.S.S.R.}

TN a paper read at the fiftieth annual meeting of 1 the Society for the Promotion of Engineering Education (United States), which has recently been published, J. G. Tolpin, of Universal Oil Products Co., described the progress of technical education in the U.S.S.R. up to the end of the third Five-Year Plan in 1942, with special reference to the engineering industries. It is a record of great achievement in the face of many difficulties, and may be viewed as both cause and effect in an unprecedented industrial expansion since 1914; especially since 1931, when Stalin said that Russia was still fifty to a hundred years behind the world's leading nations, and would have to make up this lag in ten years.

In 1914, manufacturing industry was only about one-twelfth its present size, and the whole country was still mainly agricultural. Moreover, the full extent of her vast natural resources was very inadequately realized compared with the knowledge now acquired by research and exploration. For example, it has now been discovered that the reserves of potassium minerals in Kazakhstan are the largest in the world; and the coal seams of the Pechora region are now estimated at 120,000 million tons. These and many other new discoveries of mineral wealth have meant corresponding developments in industrial activity and consequently an ever. increasing and more urgent need for trained and well-educated workers. The following figures indicate some of the progress made since 1913 :

\begin{tabular}{|c|c|c|c|c|c|}
\hline & & & 1913 & 1937 & 1942 \\
\hline output (mill. tons) & & $\cdots$ & $29 \cdot 1$ & 128 & 230 \\
\hline Iron ore & .. & $\cdots$ & $9 \cdot 2$ & $27 \cdot 8$ & $\rightarrow$ \\
\hline $\begin{array}{l}\text { Oil (mineral) } \\
\text { Sulphuric acid (1,000̉ tons) }\end{array}$ & .. & .. & $9 \cdot 1$ & $28 \cdot 4$ & $48 \cdot 5$ \\
\hline $\begin{array}{l}\text { llphuric acid (1,000 tons) } \\
\text { ectrical energy (bill. kWh.) }\end{array}$ & & . & 121 & 1,666 & 75 \\
\hline Locomotives & $\cdots$ & $\cdots$ & 664 & 1,214 & 2,090 \\
\hline
\end{tabular}

In this period the agricultural population, which represented 80 per cent of the whole in 1913, fell to 55.5 per cent of the total in 1939 ; or, in other words, the non-agricultural wage earners numbered 28 millions in 1938 as compared with 11.2 millions in 1913 ; total population increased to 170.5 millions in 1939. Industrial output has been stimulated not only through the ordinary channels of better trained workers, but also by special methods and incentives, including the distribution of medals and other decorations for specially good work, mention in the general and technical press, and by other means : at the same time poor results due to bad management or otherwise are equally publicized. The total number of youths of 14-17 at present being mobilized for industrial training is nearly $1,000,000$. After preliminary training they will work for four years on State enterprises. In the case of these and possibly other groups, it is said that special inducements are being offered to encourage them to attend the factory technical schools rather than the college grade schools, as the latter do not, it is alleged, turn out quite the right type of skilled workers for industrial plants. In the U.S.S.R., therefore, the old problem met with in other countries of striking a judicious balance between academical and practical or shop training also presents difficulties.

Looking at this matter of technical education and training in more detail, it may be said that the general school organization in the U.S.S.R., like other things in the social system, undergoes constant change, so that, as Tolpin points out, the latest official publication (1940) on school regulations is nearly all new. An important factor in this gradual evolution of the educational policy was the national convention of professors and administrative officers in May 1938, in the Moscow Kremlin, which was attended by Stalin himself. V. M. Molotov then stated that the number of students in college grade schools exceeded the combined figures for Germany, England, France, and Italy, but neither the quantitative nor qualitative objectives had been reached. The total enrolment in all types of schools in 1939 was 34 millions, of whom 600,000 studied in college grade schools. It would scarcely seem that this latter figure is an excessive proportion of the whole, or needed special efforts for its further reduction. There are no sex distinctions, and the Revolution opened all schools equally to men and women, of which the latter seem to have taken full advantage. They are now active in every field of technical and professional work and in all branches of social research. In 1939 sixty per cent of all physicians were women, and in the Bashkir country the percentage reached 75. Many of them are directors of research in medicine and other sciences, pure and applied. Women formed more than 41 per cent of the total of college students in 1939, and 27 per cent in the technical (factory) schools. The most marked advance in this respect has been in the Moslem countries (for example, Uzbekistan and Turkmenia), as might be expected, since in such countries women had much further to travel along the paths to emancipation than in others.

Nor is any distinction made in regard to national minorities or in the numerous parts of the Soviet Union where the native language is not Russian, such as the Ukraine, Georgia, Armenia, White Russia, and parts of Siberia. There are more than a hundred different languages and dialects altogether in the Union, of which more than sixty are recognized for use in public institutions. Many newspapers and 